\title{
Relationship between virulence of Streptococcus iniae strains, induc- tion of oxidative activity and cytotoxicity in rainbow trout (Oncorhyn- chus mykiss) spleen macrophages
}

\author{
A Nematollahi ${ }^{1,4}$, A Mohebbi ${ }^{2}$, A Mokhtari ${ }^{3}$ and S K Baruah ${ }^{4}$ \\ ${ }^{1}$ Division of Aquatic Animal Health and Diseases, Department of Food Hygiene and Quality Control, \\ Faculty of Veterinary Medicine, Shahrekord University, Shahrekord, Iran \\ ${ }^{2}$ Department of of Clinical Sciences, Faculty of Veterinary Medicine, Shahrekord University, Shahrekord, Iran \\ ${ }^{3}$ Departments of Aquatic Animal Health and Diseases, Faculty of Veterinary Medicine, University of Tehran, \\ Tehran, Iran \\ ${ }^{4}$ Laboratory of Aquaculture and Artemia Reference Centre, Faculty of Bioscience Engineering, Ghent University, \\ Belgium
}

Received: April 2014

\begin{abstract}
In the present study, the effect of the high and low virulence Streptococcus iniae strains on oxidative activity and cytotoxic effects of trout spleen macrophages were studied. Spleen macrophages were collected from trout. Luminol was used as chemiluminigenic probe. Phorbolmyristate acetate (PMA) also was used as positive control activating agent of respiratory burst and significantly stimulated production of reactive oxygen species (ROS) by normal macrophages. Sensitivity of $S$. iniae strains to $\mathrm{H} 2 \mathrm{O} 2$ and cytotoxicity of bacterial strains for trout macrophages was also determined using the antibacterial effect of $\mathrm{H} 2 \mathrm{O} 2$ and the release of lactate dehydrogenase from infected macrophages, respectively. Spleen macrophages produced ROS upon stimulation with both bacterial strains. Approximately twofold as much ROS production was induced by the high virulence strain compared to the low virulence strain. The low virulence strain was killed approximately 6 times more by $\mathrm{H}_{2} \mathrm{O}_{2}$ compared to the high virulence strain. In spleen mac-
\end{abstract}

Correspondence A Nematollahi, Division of Aquatic Animal Health and Diseases, Department of Food Hygiene and Quality Control, Faculty of Veterinary Medicine, Shahrekord University, Shahrekord, Iran (email: anematolahi@yahoo. com)
Accepted: August 2014

rophages, the highly virulent strain caused approximately twice as much cytotoxic effects compared to the low virulent strain. Results indicate that, high virulence in $S$. iniae appears to be correlated with higher macrophage cytotoxicity and resistance to ROS. Moreover, significant differences between the strains in their capacity to stimulate the macrophages were observed $(\mathrm{P}<0.05)$.

Keywords: rainbow trout, Streptococcus iniae, reactive oxygen species, chemiluminescence, macrophage.

\section{Introduction}

Streptococcus iniae is a Gram-positive, sphereshaped bacterium which most often occurs in long chains in broth culture (Austin \& Austin 1999; Lau, Woo, Luk, Fung, Hui, Fong, Chow, Wong \& Yuen 2006; Agnew \& Barnes 2007). This bacterium is the causal agent of Streptococcusis in many fish species. Since its isolation from an Amazon freshwater dolphin, $S$. iniae has emerged as a leading fish pathogen in aquaculture operations worldwide. $S$. iniae has been reported to cause disease in more than two dozen species of fish from both freshwater and saltwater environments. This pathogen has also been associated with disease outbreaks in different commercial fish species such as rainbow trout, tilapia, channel catfish, gilthead sea bream or sea 
bass (Baya, Lupiani, Hetrick, Roberson, Lukacovic, May \& Poukish 1990; Zlotkin, Hershko \& Eldar 1998; Soltani, Jamshidi \& Sharifpour 2005; Agnew et al. 2007). In outbreaks of Streptococcusis, mortalities of 30 to $50 \%$ are reported (Kaige, Miyazaki \& Kubota 1984; Zlotkin et al. 1998; Agnew et al. 2007;). In addition to its importance in aquaculture, S.iniae is capable of causing disease in humans who have recently handled infected fish from aquaculture farms (Weinstein, Litt, Kertesz, Wyper, Rose, Coulter, McGeer, Facklam, Ostach, Willey, Borczyk \& Low 1997).

This bacterium was initially isolated from subcutaneous abscesses on Amazon freshwater dolphins (Pier \& Madin 1976), and the pathology of the disease caused by this pathogen had been described in rainbow trout by Eldar and Ghittino (1999).

In spite of the importance of S. iniae as a fish pathogen and the significant increasing of the disease, the data relating to its pathogenesis to provide sufficient scientific information for an efficient control strategy, and the first step of the interaction between this pathogen and fish, are lacking. So far there is limited information available about the interaction of this bacterium and immune defence mechanisms of the fish.

It has been postulated previously that macrophages are extremely important in specific as well as non-specific immune responses against invading microorganisms. Spleen has also shown to be a rich source of macrophages in fish (Secombes \& Fletcher 1992; Ellis 1999). Respiratory burst generated by macrophages has been recognized as one of the major contributors to the killing of pathogens. This phenomenon is accompanied by the production and release of highly reactive oxygen metabolites. Reversion of the unstable oxygen metabolites to their ground state is responsible for the emission of photons, which has been termed chemiluminescence (Rossi, Bianca \& de Togni 1985). Additionally, it has been found that the spleen tissue from naturally infected fish with $S$. iniae revealed the presence of phagosomes and residual bodies indicative of extensive lysosomal activity within the phagocytes (Bromage \& Owens 2002; Kaige et al. 1984). However, the appearance of numerous encapsulated coccus bacteria and extensive degeneration of the spleen tissue suggested that the response to the pathogen was not effective (Eldar, Frelier, Assenta, Varner, Lawhon \& Bercovier 1995; Agnew et al. 2007; Soltani, Nikbakht, Mousavi \& Ahmadzadeh 2008).

In the present study, the effect of a high and a low virulence $S$. iniae strains on oxidative activity and cytotoxic effects of trout spleen macrophages were investigated. This study aims at deciphering in greater depth of the association between bacterial virulence and interactions of $S$. iniae with trout macrophages.

\section{Materials and Methods}

\section{Fish}

Twelve rainbow trout (mean weight $750 \mathrm{~g}$ ) were obtained from a commercial fish farm, and kept in a flow through system (1000L tank) containing aerated well water $\left(14-16^{\circ} \mathrm{C}\right)$ for two weeks prior to experimentation. Fish were fed daily with a commercial diet. All fishes were clinically healthy and found to be free of external parasite infestations. The presence of $S$. iniae was assessed by streaking swabs from the spleen and kidney onto tryptic soy agar (TSA) supplemented with 5\% de-fibrinated sheep blood. Plates were incubated at $27-30^{\circ} \mathrm{C}$ for 24-48 h (Soltani et al. 2008). S. Iniae was not isolated from randomly selected fish.

\section{Macrophages}

Spleen macrophages were collected according to the procedures of Nematollahi, Pasmans, Haesebrouck \& Decostere (2005). Briefly, fish were euthanized using an overdose of a solution of benzocaine (ethilaminobenzoate) in ethanol $(1 \mathrm{~g} / 10 \mathrm{~mL})$. The spleen $(3 \pm 1 \mathrm{~g})$ was aseptically removed and pushed through a $150 \mu \mathrm{m}$ nylon mesh (Solana NV, Schoten) with Dulbecco's Modified Eagle Medium (DMEM, Gibco) containing 5\% Foetal Calf Serum (Jitegro, aaDierea), 1\% non-essential amino-acids (Gibco), 1\% Glutamine (Gibco), $100 \mathrm{IU} \mathrm{mL}^{-1}$ penicillin (Gibco) $100 \mathrm{mg} \mathrm{mL}^{-1}$ streptomycin (Gibco), $100 \mathrm{mg} \mathrm{mL}^{-1}$ kanamycine sulphate (Gibco) and 10 IU $\mathrm{mL}^{-1}$ heparin. Then, the cell suspension was 
layered onto a discontinuous 34\% / 51\% Percoll gradient (Pharmacia Biotech). After centrifugation $\left(400 \times \mathrm{g}, 25 \mathrm{~min}, 4^{\circ} \mathrm{C}\right)$, the band of the cells lying at the $34-51 \%$ interface of Percoll suspension was collected and washed once with sterile Hanks' balanced salt solution (HBSS; Gibco) without $\mathrm{Ca}$ / $\mathrm{Mg}$. For identification of cells, air-dried smears of the different samples were stained with Heamacolor $^{\circledR}$ stain (Merck) and observed under the light microscope at magnification $\mathrm{x} 1000$. The presence of non-specific esterase activity was determined using the $\alpha$-naphtyl butyrate esterase staining kit (Sigma Diagnostic). The cells were counted using a Burker counting chamber and their viability was determined by exclusion of trypan blue. The cells were then adjusted to $10^{7}$ macrophages $\mathrm{mL}^{-1}$ and $100 \mu \mathrm{L}$ volumes were cultivated in 96-well plates. To assess whether spleen macrophages adhere well to the 96-well plate, the cells seeded in plate with flat bottom (Iwaki Microplate) and incubated for $24 \mathrm{~h}$ at $17^{\circ} \mathrm{C}$ and $5 \% \mathrm{CO}_{2}$. After gently rinsing two times with PBS, the cells were harvested by adding $20 \mu \mathrm{L}$ trypsin solution per well, based on $88 \mathrm{~mL}$ trypsin diluent $(\mathrm{NaCl} 8 \mathrm{~g}, \mathrm{KCl} 0.2$ g, KH2PO4 0.12 g, NaH2PO4 $0.91 \mathrm{~g}$, phenolred $0.5 \%$ and aqua dest $1000 \mathrm{~mL}$ ), $10 \mathrm{~mL}$ trypsin stock $2.5 \%$ (Gibo) and 2 $\mathrm{mL}$ versenate ( $2 \mathrm{~g}$ EDTA in $100 \mathrm{~mL}$ trypsin diluent). After $10 \mathrm{~min}$ incubation $\left(37^{\circ} \mathrm{C}, 5 \% \mathrm{CO} 2\right)$, the cells were re-suspended in $100 \mu \mathrm{LMEM}$ and counted using a Burker counting chamber.

\section{Bacterial strains}

Two $S$. iniae strains were used: Strain 1(high virulent) and Strain 2 (low virulent). Strain 1 was isolated from trout spleen and kidney in a Streptococcusis outbreak in Fars province with 50\% mortality, Iran (Akhlaghi \& Keshavarzi 2002). Strain 2 was recovered in Shahrekord, Iran from the internal organs of rainbow trout with $10 \%$ mortality. In order to preserve virulent properties, both strains were stored virtually immediately following in vivo isolation. After intraperitoneal inoculation, Strain 1 proved to be of highly virulent whereas Strain 2 was found to be of low virulent (Akhlaghi \& Keshavarzi 2002). The isolate was grown in tryptic soy broth for $24 \mathrm{~h}$ at $27-30^{\circ} \mathrm{C}$, and then the culture was frozen at -70 ${ }^{\circ} \mathrm{C}$ in $0.2 \mathrm{~mL}$ aliquots with $15 \%$ glycerol (v/v). After thawing, the bacteria were grown for 24-48 $\mathrm{h}$ in 4 $\mathrm{mL}$ of tryptic soy broth at $27-30^{\circ} \mathrm{C}$. Subsequently, the cultured broth was centrifuged ( $3000 \mathrm{~g}, 10 \mathrm{~min}$, $15^{\circ} \mathrm{C}$ ) and the resulting pellet and supernatant were separated. The pellet was re-suspended in DMEM medium without phenolred. The number of colony forming units (CFU) was determined by plating 10fold serial dilutions on TSA supplemented with 5\% de-fibrinated sheep blood plate (Soltani et al. 2008).

\section{Oxidative activity of spleen macrophages}

The generation of $\mathrm{O}_{2}$ - by rainbow trout macrophages (ROS production) was determined by chemiluminescence (CL) assay (Rossi et al. 1985). The assay was performed in a microplateluminometer (Thermo Labsystems), using sterile 96-well plates with clear bottom (Greiner bio-one $\mathrm{GmbH}$ ) at $27^{\circ} \mathrm{C}$. Luminol (Sigma Biosciences) was used as chemiluminigenic probe. Luminol was dissolved in dimethyl sulfoxide (Sigma) to give a concentration of 104 $\mathrm{mM}$. Prior to use, the luminol stock was thawed and diluted in HBSS to final concentration of $200 \mu \mathrm{M}$.

After $24 \mathrm{~h}$ incubation at $16^{\circ} \mathrm{C}$ and $5 \% \mathrm{CO}_{2}$ allowing adherence of the cells, the cell culture medium was replaced by $100 \mu \mathrm{HBSS}$ and $25 \mu \mathrm{l}$ of diluted luminol solution in HBSS. Then, the plates were placed in luminometer and the CL background value was recorded for $10 \mathrm{~min}$. Data were collected at 2 min interval times. After stabilisation of the background value, $50 \mu \mathrm{l}$ of either of the bacterial strains to be tested, were added per well (first stimulation). The addition of $50 \mu \mathrm{l}$ of phorbolmyristate acetate (PMA) (Sigma), final concentration $70 \mu \mathrm{g} \mathrm{mL} \mathrm{L}^{-1}$, to non-infected macrophages was used as positive control. Negative control samples were also included in each CL assay. The plates then were placed in luminometer and the CL value was recorded for 2 h. In order to assess the macrophages viability after the first stimulation, PMA $(25 \mu \mathrm{l})$ with concentration $160 \mu \mathrm{g} \mathrm{mL}^{-1}$ were added to both control and infected wells and the CL responses measured for 1 $\mathrm{h}$ (second stimulation). Each CL assay was repeated four times in triplicate, depending on the macro- 
phage yield. The ROS productions are presented as area under the curve (AUC).

\section{Sensitivity of $S$. Iniae strain to $\mathrm{H}_{2} \mathrm{O}_{2}$}

In order to determine the role of ROS in bacterial killing, the antibacterial effect of $\mathrm{H}_{2} \mathrm{O}_{2}$ was evaluated. Briefly, $5 \mathrm{~mL}$ of tryptic soy broth containing $40 \mathrm{mM} \mathrm{H} \mathrm{O}_{2}$ were mixed with $5 \mathrm{~mL}$ of either of the bacterial suspensions containing $108 \mathrm{CFU} \mathrm{mL}^{-1}$ and incubated at $27^{\circ} \mathrm{C}$. The number of CFU was enumerated at $\mathrm{t}=30$ and $\mathrm{t}=60 \mathrm{~min}$ after incubation time by plating ten-fold serial dilutions on TSA plates in triplicate (Barnes, Bowden, Horne \& Ellis 1999; Nematollahi et al. 2005).

\section{Cytotoxicity of $S$. iniae strains for rainbow trout macrophages}

In order to measure cytotoxic effects of a low and a high virulent strain of $S$. iniae to spleen macrophages, the release of lactate dehydrogenase $(\mathrm{LDH}$, Roche) from infected macrophages was assessed according to the method of Korzenieweski and Callewaert (1983) with some modifications. Inoculation of the macrophages was performed as described previously. Un-inoculated wells were used as negative control. Positive control samples consisted of macrophages in $175 \mu$ medium, lysed with $25 \mu \mathrm{l}$ of $2 \%$ Triton X-100 for $15 \mathrm{~min}$. Following centrifugation $\left(250 \times \mathrm{g}, 10 \mathrm{~min}, 4^{\circ} \mathrm{C}\right)$ the $\mathrm{LDH}$ level of the supernatant was determined according to the manufacturer's instructions. The absorbency at $492 \mathrm{~nm}$ was recorded Spectrophotometrically. The percentage cytotoxicity was calculated adopting the following formula:

Cytotoxicity =Absorbency - Average absorbency negative control $\times 100 /$ Average absorbency positive control - Average absorbency negative control

\section{Statistical analysis}

The results of each experiment were compared using the one way ANOVA test (computer program Sigma Stat, Analytical Software). Results were expressed as mean \pm standard error of experiments. A value of $\mathrm{P}<0.05$ was considered statistically significant.

\section{Results}

\section{Collection of macrophages}

Approximately $10^{7}$ macrophages were harvested from each rainbow trout spleen. The average proportion of esterase positive cells (macrophages) was more than $95 \%$ of the cells in suspension. The viability also exceeded $98 \%$. No significant differences in adhesive capacity were noted between the spleen macrophages before and after rinsing.

\section{Oxidative activity of spleen macrophages}

Results of ROS production were given in Figure 1. Spleen macrophages produced ROS upon stimulation with a high and a low virulence strain of $S$. iniae as measured using CL. PMA was used as a positive control activating agent of the respiratory burst and this significantly stimulated ROS production by normal macrophages (Fig. 1). However, the level of ROS during the first stimulation (after $2 \mathrm{~h}$ ) following infection with strain 1 was higher than strain 2. Similarly, significant differences were found in area under the curve (AUC) values between $S$. iniae strains and PMA $(\mathrm{P}<0.05)$. A twofold higher ROS production was induced by the high virulence strain compared to the low virulence strain $(\mathrm{P}<0.05)$. All negative controls included in the first stimulation of each CL assay gave low AUC values. Likewise, overall ROS production was demonstrated a significant difference between high and low virulence strains $(\mathrm{P}<0.05)$. Regarding the viability of macrophages after each CL assay, the macrophages could still be stimulated by PMA, $1 \mathrm{~h}$ later (second stimulation). The addition of PMA to the infected macrophages did not increase ROS production above the level of control non-infected macrophages and the level of ROS was significantly lower than control $(\mathrm{P}<0.05)$ (Fig. 2).

\section{Sensitivity of $S$. iniae strain to $\mathrm{H}_{2} \mathrm{O}_{2}$}

Results of bacterial survival of two $S$. iniae strains after exposure to $\mathrm{H}^{2} \mathrm{O}^{2}$ were summarized in Figure 2. As shown, both strains were viable after 30 and $60 \mathrm{~min}$, respectively. The low virulence strain was killed approximately 6 times more than the high 


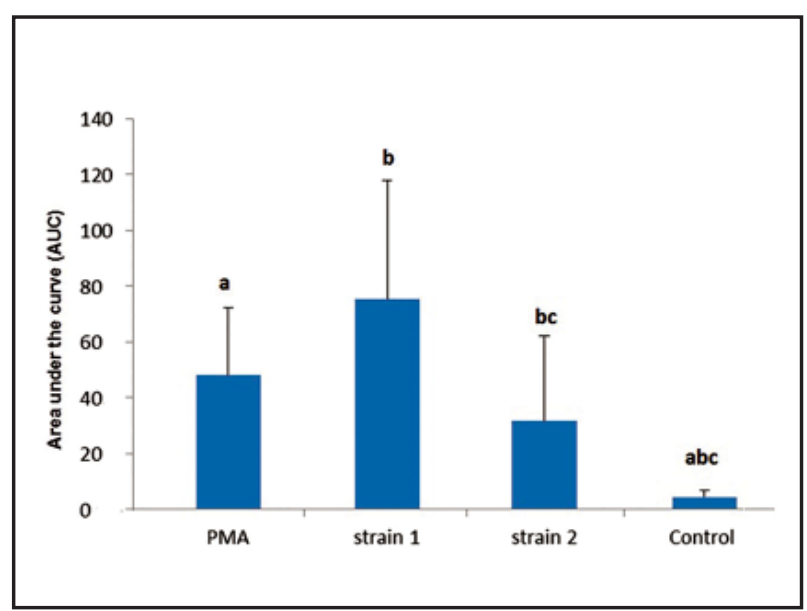

Figure 1 Mean ROS production + SE of spleen macrophages from rainbow trout after exposure to PMA, a high (Strain 1) or of a low (Strain 2) virulence strain of $S$. iniae. Data represents the mean of 5 independent experiments (+SE). The same letter $(\mathrm{a}-\mathrm{c})$ refers to a statistically significant difference $(\mathrm{P}<0.05)$.

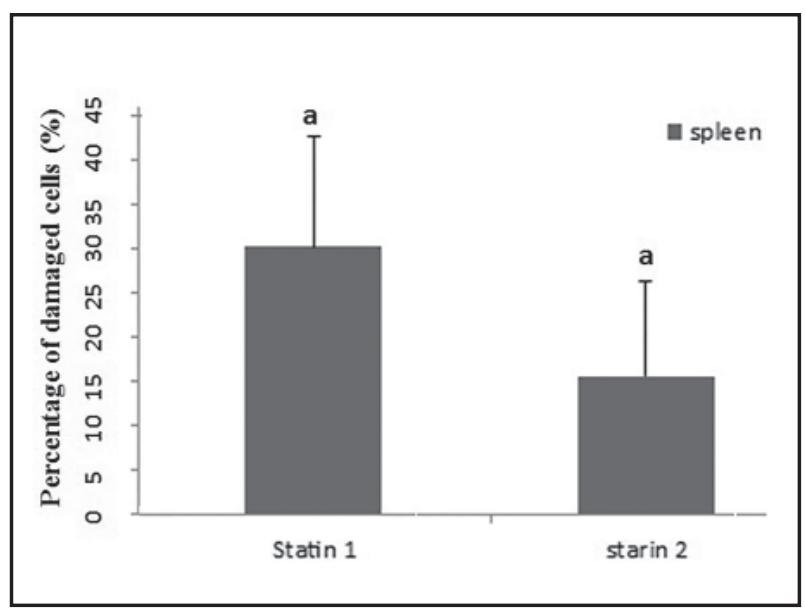

Figure 3 Cytotoxic effect of a low (Strain 2) and a high (Strain 1) virulence strain of $S$. iniae on spleen macrophages from rainbow trout. The data are presented as mean \% of damaged cells $+\mathrm{SE}$ of 4 independent experiments. The same letter refers to a statistically significant difference $(\mathrm{P}<0.05)$.

virulence strain $(\mathrm{P}<0.05)$ over the 30 and $60 \mathrm{~min}$ periods.

\section{Cytotoxicity of $S$. iniae strains for rainbow trout macrophages}

Both $S$. iniae strains were cytotoxic for spleen macrophages (Fig. 3). In spleen macrophages, the highly virulent strain caused twice as much cytotoxic effects compared to the low virulent strain $(\mathrm{P}<0.05)$.

\section{Discussion}

Fish rely on both specific and non-specific immune

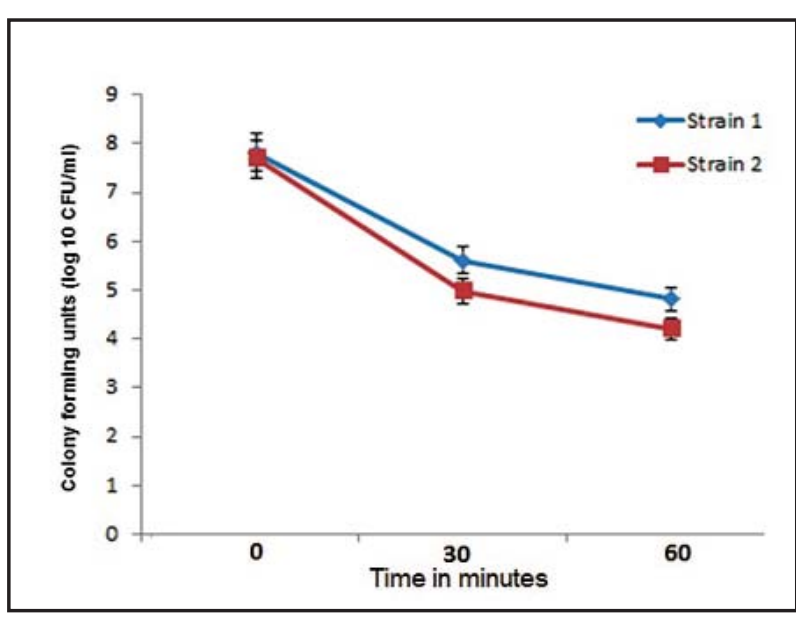

Figure 2 Survival of a low (Strain 2) and a high (Strain 1) virulence strain of $S$. iniae in the presence of $\mathrm{H} 2 \mathrm{O} 2$. The data are presented as the average log (10) of the number of CFU between 0,30 and 60 min after exposure $\pm \mathrm{SE}$.

mechanisms to protect themselves against various pathogens. Macrophages are the most important cells involved defense mechanisms in fish. Several ROS are produced by fish macrophages during the oxidative activity such as superoxide anion $\left(\mathrm{O}_{2}^{-}\right)$, hydrogen peroxide $\left(\mathrm{H}_{2} \mathrm{O}_{2}\right)$, hydroxyl radical $\left(\mathrm{OH}^{-}\right)$, singlet oxygen $\left(1 \mathrm{O}_{2}\right)$ (Ellis 1999; Secombes $\&$ Fletcher 1992). ROS establish an important component of the innate immune response against invading pathogens by fish macrophages. Therefore, fish pathogens must overcome the toxic effects of ROS to establish infections. Bacteria have evolved systems to protect themselves from these toxic radicals. One of these protective pathways involves the production of detoxifying enzymes such as superoxide dismutases (SODs) and catalases. Productions of SOD and catalase enzymes have been reported to contribute to the virulence of a great number of fish pathogens (Austin \& Austin 1999; Barnes et al. 1999; Ellis 1999; Barnes, Young, Horne \& Ellis 2003; Nematollahi et al. 2005).

In the present study, trout spleen macrophages produced ROS upon stimulation with both $S$. iniae strains. A twofold higher ROS production was induced by the high virulence (strain 1) compared to the low virulence one (strain 2). However, when the macrophages were infected with the low virulence strain, the ROS production was suppressed compared to stimulate with high virulence strain 


\section{A Nematollahi et al., Virulence of $S$. Iniae and cytotoxicity in trout macrophages}

and non-infected control macrophages. This lack of induction of ROS was observed both at first and second stimulation. This finding suggests that ROS production was inhibited by the low virulence strain or alternatively that this strain did not activate the production of ROS. The latter seems unlikely as the infected macrophages were unresponsive to PMA, suggesting inhibition or exhaustion of ROS.

Our finding is in agreement with Buchanan, Colvin, Vicknair, Patel, Timmer \& Nizet (2008) who reported that the a virulent strain of $S$. iniae was susceptible to reactive oxygen species and rapidly killed within macrophages. The avirulent strain was found to be markedly more susceptible to killing by hydrogen peroxide and singlet oxygen than other virulent strains. This group also reported that the loss of virulence in strain of $S$. iniae is not associated with decreased hemolytic activity, cellular adherence, or intracellular invasion (Buchanan et al. 2008). Several studies have reported the high affinity of high-virulent strains of $S$. iniae to macrophage reach organs such as kidney, spleen and liver. However, this strong affinity is not resulted to higher killing by macrophages (Akhlaghi \& Mahjor 2004; Soltani et al. 2005). The results of the present study revealed a lower sensitivity of the high virulence strain to killing by $\mathrm{H}_{2} \mathrm{O}_{2}$ compared to the low virulence strain. It seems that in spite of stronger induction of ROS by spleen macrophages against high virulence strain, this strain was killed to a lesser extent (Soltani et al. 2005).

Several virulence factors have been identified in $S$. iniae species. The first one which present in all isolates is capsule however, in serotype II, this part is providing more coverage of surface antigens, thereby conferring additional anti-phagocytic properties. Capsule has also been shown to play an important role in resistance to phagocytic clearance by fish macrophages (Barnes et al. 2003; Buchanan, Stannard, Lauth, Ostland, Powell, Westerman \& Nizet 2005). Protection against the macrophage bactericidal mechanisms enables the bacteria to reside inside these cells, protected against both humoral response and host complement. Therefore, resistance to bacterial killing by the fish macrophages may constitute an important virulence factor of $S$. iniae confirming the results of Buchanan et al. (2008). Based on our results, the spleen macrophages produced more ROS and killed more high virulent bacteria than the low virulent one. Interestingly, $S$. iniae bacteria proved to be cytotoxic for rainbow trout macrophages, resulting in fairly high losses of viable macrophages at $2 \mathrm{~h}$ post inoculation. This finding suggests that spleen macrophages are more tolerant for harbouring the low virulent $S$. iniae bacteria and hence may constitute a safer site for this bacterium to reside in. This hypothesis is supported by earlier studies, in which the spleen proved to be one of the target organs of the $S$. iniae (Akhlaghi \& Mahjor 2004; Soltani et al. 2005). However, it is important to study the interaction of macrophages with live bacteria as many pathogens can subvert ROS and survive in macrophages such as Renibacteriumsalmoninarum (Campos-Pérez, Ellis \& Secombes 1997), Aeromonassalmonicida (Barnes et al. 1999), Vibrio anguillarumserogroup $\mathrm{O} 1$ and O2a (Boesen, Larsen, Larsen \& Ellis 2001), Flavobacterium psychrophilum (Nematollahi et al. 2005). Likewise, there is very few information available on the interaction of salmonid macrophages with $S$. ini$a e$ and the role of ROS in bactericidal activity of macrophages. Buchanan et al. (2008) demonstrated that $S$. iniae bacteria were able to induce ROS in phagocytes. In this process, they found that the metabolites and/or bacterial components of $S$. iniae were able to stimulate phagocytes and they did observe significant differences between the strains in their capacity to stimulate the phagocytes. Indeed, adherence of the pathogen to the phagocyte membrane or vice versa can be sufficient to cause the release oxidative radicals. It was speculated that the differences between $S$. iniae strains may be present in the stages following initial contact of the bacterium phagocyte interaction reflecting an inequality in virulence (Buchanan et al. 2008).

Rainbow trout macrophages also generate $\mathrm{H}_{2} \mathrm{O}_{2}$ during the oxidative burst (Secombes, Chung \& Jeffries 1988). This study revealed that the susceptibility of low virulence strain was not similar to that of high virulence strain. There also seems to be a 
difference in induction of $\mathrm{H}_{2} \mathrm{O}_{2}$ by the two $S$. iniae strains. However, unlike the high virulence strain, the resistance of low virulence strain to $\mathrm{H}_{2} \mathrm{O}_{2}$ was not up-regulated when exposed to $\mathrm{H}_{2} \mathrm{O}_{2}$ during growth. This might be a necessary in vivo resistance mechanism to avoid macrophage killing that the low virulence bacterium does not possess and therefore it will have less chance of surviving in the fish than high virulence strain. Several studies demonstrated $\mathrm{H}_{2} \mathrm{O}_{2}$ production by trout macrophages infected with $V$. anguillarum and A. Salmonicida (Boesen et al. 2001; Barnes et al. 2003).

In conclusion, the present study documented that high virulence in $S$. iniae strains appears to be correlated with higher macrophage cytotoxicity and resistance to ROS and, therefore, with enhanced resistance to bacterial killing by rainbow trout spleen macrophages.Additional study is needed in regard to development of in vitro assays to assess virulence factors of $S$. iniae.

\section{Acknowledgements}

This study was financially supported by Shahrekord University, Shahrekord, Iran. Mr. Khosravi and Mr. R. Safarpour are acknowledged for their skilled technical assistance. The Shahrekord University of Iran also is thanked for providing a sabbatical grant to Amin Nematollahi.

\section{References}

Agnew W. \& Barnes AC. (2007) Streptococcus iniae: an aquatic pathogen of global veterinary significance and a challenging candidate for reliable vaccination. Veternary Microbiology 122, 1-15.

Akhlaghi M. \& Keshavarzi M. (2002) The occurrence of streptococcosis in the cultured rainbow trout of Fars province. Iranian Journal of Veternary Research 2, 183189.

Akhlaghi M. \& Mahjor A.A. (2004) Some histopathological aspects of streptococcosis in cultured rainbow trout (Oncorhynchus mykiss). Bulletin of the European Association of Fish Pathologists 24, 132-136.
Austin B. \& Austin D. (1999) Bacterial fish pathogens: Disease of farmed and wild fish, $3^{\text {rd }}$ edn. Praxis Publishing Ltd, Chichester, UK.

Barnes A.C., Bowden T.J., Horne M.T. \& Ellis A.E. (1999) Peroxide-inducible catalase in Aeromonas salmonocida subsp. salmonicida protects against exogenous hydrogen peroxide and killing by activated rainbow trout, Oncorhynchus mykiss L., macrophages. Microbial Pathogenesis 26, 149-158.

Barnes A.C., Young F.M., Horne M.T. \& Ellis A.E. (2003) Streptococcus iniae: serological differences, presence of capsule and resistance to immune serum killing. Diseases of Aquatic Organisms 53, 241-247.

Baya A.M., Lupiani B., Hetrick F.M., Roberson B.S., Lukacovic R., May E. \& Poukish, C. (1990) Association of Streptococcus sp. with fish mortalities in the Chesapeake Bay and its tributaries. Journal of Fish Diseases 13, 251253.

Boesen H.T., Larsen M.H., Larsen J.L. \& Ellis A.E. (2001) In vitro interaction between rainbow trout (Oncorhynchus mykiss) macrophages and Vibrio anguillarum serogroup O2a. Fish and Shellfish Immunology 11, 415-31.

Bromage E.S. \& Owens L. (2002) Infection of barramundi Lates calcarifer with Streptococcus iniae: effects of different routes of exposure. Diseases of Aquatic Organisms 52, 199-205.

Buchanan J.T., Stannard J.A., Lauth X., Ostland V.E., Powell H.C., Westerman M.E. \& Nizet V. (2005) Streptococcus iniae phosphoglucomutase is a virulence factor and a target for vaccine development. Infection and Immunity 73, 6935-6944.

Buchanan J.T., Colvin K.M., Vicknair M.R., Patel S.K., Timmer A.M. \& Nizet V. (2008) Strain-associated virulence factors of Streptococcus iniae in hybrid-striped bass. Veterinary Microbiology 131, 145-153.

Campos-Pérez J.J., Ellis A.E. \& Secombes C.J. (1997) In- 


\section{A Nematollahi et al., Virulence of $S$. Iniae and cytotoxicity in trout macrophages}

vestigation of factors influencing the ability of Renibacterium salmoninarum to stimulate rainbow trout macrophages respiratory burst activity. Fish and Shellfish Immunology 7, 555-566.

Eldar A., Frelier P., Assenta L., Varner P., Lawhon S. \& Bercovier H. (1995) Streptococcus shiloi, the name for an agent causing septicemic infection in fish, is a junior synonym of Streptococcus iniae. International Journal of Systematic and Evolutionary Microbiology 45, 840.

Eldar A. \& Ghittino C. (1999) Lactococcus garvieae and Streptococcus iniae infections in rainbow trout Oncorhynchus mykiss: similar, but different diseases. Diseases of Aquatic Organisms 36, 227-231.

Ellis A.E. (1999) Immunity to bacteria in fish. Fish and Shellfish Immunology 9, 291-308.

Kaige N., Miyazaki T. \& Kubota S. (1984) The pathogen and the histopathology of vertebral deformity in cultured yellowtail. Fish Pathology 19, 173-179.

Korzenieweski C. \& Callewaert D.M. (1983) An enzyme-release assay for natural cytotoxicity. Journal of Immunological Methods 64, 313-320.

Lau S., Woo P., Luk W., Fung A., Hui W., Fong A., Chow C., Wong S. \& Yuen K. (2006) Clinical isolates of Streptococcus iniae from Asia are more mucoid and -hemolytic than those from North America. Diagnostic Microbiology and Infectious Disease 54, 177-181.

Nematollahi A., Pasmans F., Haesebrouck F. \& Decostere A. (2005) Early interactions of Flavobacterium psychrophilum with macrophages of rainbow trout (Oncorhynchus mykiss). Diseases of Aquatic Organisms 64, 23-28.

Pier G.B. \& Madin S.H. (1976) Streptococcus iniae sp. nov., a betahemolytic Streptococcus isolated from an Amazon freshwater dolphin, Inia geoffrensis. International Journal of Systematic Bacteriology 26, 545-553.

Rossi F., Bianca B.D. \& de Togni P. (1985) Mechanisms and functions of the oxygen radicals producing respira- tion of phagocytes. Comparative Immunology, Microbiology and Infectious Diseases 8, 187-204.

Secombes C.J., Chung S. \& Jeffries A.H. (1988) Superoxide anion production by rainbow trout macrophages detected by the reduction of ferricytochrome C. Developmental and Comparative Immunology 12, 201-206.

Secombes C.J. \& Fletcher T.C. (1992) The role of phagocytes in the protective mechanisms of fish. Annual Review of Fish Diseases 2, 53-71.

Soltani M., Jamshidi Sh. \& Sharifpour I. (2005) Streptococcosis caused by Streptococcus iniae in farmed rainbow trout (O. mykiss) in Iran : biophysical characteristics and pathogenesis. Bulletin of the European Association of Fish Pathologists 25, 95-107.

Soltani M., Nikbakht GH., Mousavi H.A.E. \& Ahmadzadeh N. (2008) Epizootic outbreaks of lactococcosis caused by Lactococcus garvieae in farmed rainbow trout (Oncorhynchus mykiss) in Iran. Bulletin of the European Association of Fish Pathologists 28, 207-212.

Weinstein MR., Litt M., Kertesz D.A., Wyper P., Rose D., Coulter M., McGeer A., Facklam R., Ostach C., Willey BM., Borczyk A., Low DE. (1997) Invasive infections due to a fish pathogen, Streptococcus iniae. New England Journal of Medicine 337, 589-590.

Zlotkin A., Hershko H. and Eldar A. (1998) Possible transmission of Streptococcus iniae from wild fish to cultured marine fish. Applied and Environmental Microbiology 64, 4065-4067. 


\title{
مطالعه ارتباط بين حدت سويههاى استريتو كو كوس اينيايى

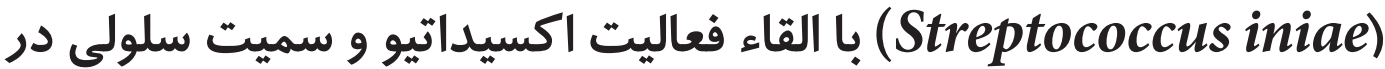 ماكروفازهاى طحال قزل آلاى رنكين كمان (Oncorhynchus smykiss)
}

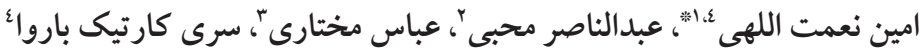

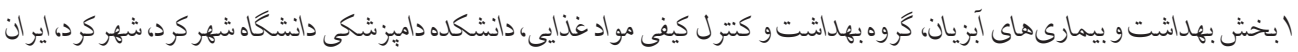

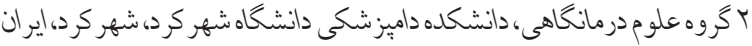

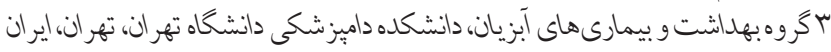

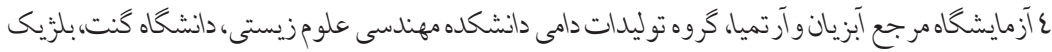

\begin{abstract}
در مطالعه حاضر تاثير سويههاى ير حدت و مم حدت استريتوكوكوس اينيايى بر روى فعاليتهاى اكسيداتيو واثرات سيتوتوكسيك ماكروفازهاى طحال

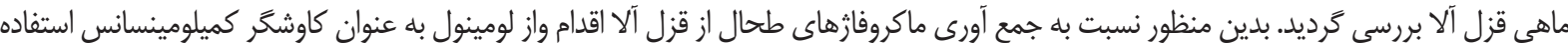

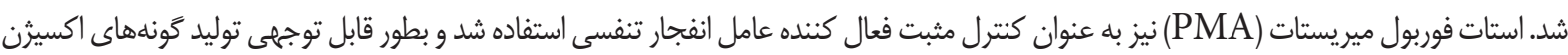

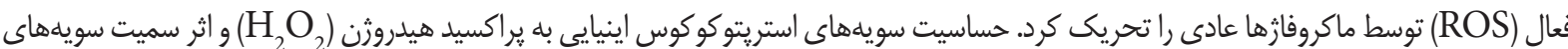

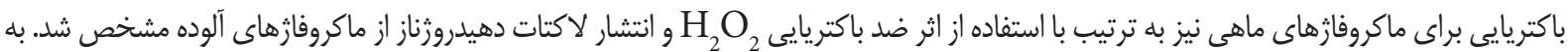

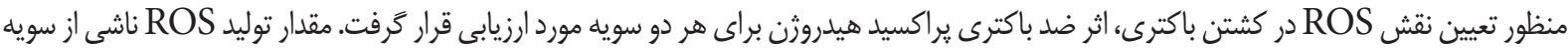

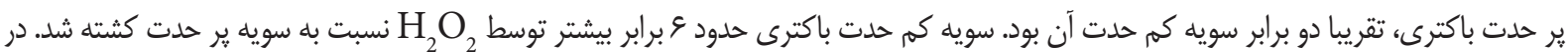

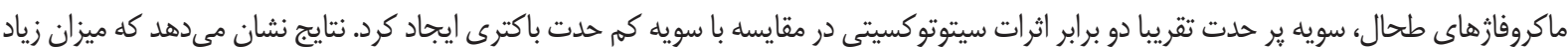

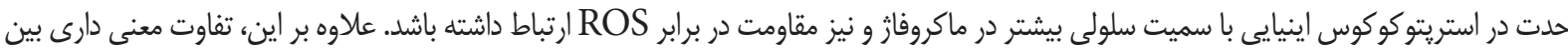
سويdهاى باكترى درظرفيت تحريكى ماكروفازها مشاهده كر ديد. وازههاى كليدى: قزل آلاى رنخين كمان، استريتوكو كوس اينيايى، كونهاى اكسيرن فعال، كميلومينسانس، ماكروفاز. anematolahi@yahoo.com :ويسنده مسئول***
\end{abstract}

جكيده 